\title{
Multiple Oral Lipomas of the Tongue: Case Report
}

\author{
Kyung-Eun Lee ${ }^{1.3}$, D.D.S.,Ph.D., Seung-O Ko ${ }^{2.3}$, D.D.S.,Ph.D., Jin-seok Byun ${ }^{4}$, D.D.S., M.S.D., \\ Bong-Jik Suh ${ }^{1,3}$, D.D.S.,Ph.D. \\ Department of Oral Medicine, Department of Oral Maxillofacial Surgery', \\ School of Dentistry, Chonbuk National University \\ Institute of Oral Biosciences, Chonbuk National University" \\ Graduate School of Medical Science and Engineering, KAIST
}

\begin{abstract}
Lipoma is a benign tumor composed of mature adipocytes and the most common soft tissue mesenchymal neoplasm but relatively rare in the oral cavity. Lipoma of the tongue is uncommon and especially multiple lipomas are quite rare and only several cases of those were reported. We describe an unusual case of multiple lipomas of the tongue.
\end{abstract}

Key words : Multiple lipomas, Oral lipoma, Tongue

\section{I . INTRODUCTION}

Lipoma is a benign tumor composed of mature adipocytes and the most common soft tissue mesenchymal neoplasm in adults. The etiology of lipoma is uncertain. ${ }^{1}$ It may arise in almost any part of the human body where adipose tissue is present and mainly affects the region of the trunk and proximal portion of extremities. ${ }^{1,2}$ But it is relatively rare in the oral cavity. ${ }^{3}$

The most common site in the oral cavity is the buccal mucosa followed by the lip, tongue, floor of mouth. ${ }^{4}$ Lipoma is mainly solitary and approximately $5 \%$ of patients have multiple. ${ }^{1}$ But there is no known data of multiple lipomas in oral cavity. Only four cases of multiple lipomas of the tongue

Corresponding author : Bong-Jik Suh

664-14 Dukjin-Dong, Dukjin-Gu, Jeonju, Korea, 561-756 Tel. +82 0632502054; Fax +820632502058

E-mail address: yonam@jbnu.ac.kr

Received: 2012-05-30

Revised: 2012-07-11

Accepted: 2012-08-05 were reported in English literatures from Germany, Japan, Turkey. ${ }^{5-8}$ In this article, we report the rare case of multiple oral lipomas on the tongue of Korean male.

\section{CASE REPORT}

A 71-year-old patient with painless swelling of the right border of the tongue visited department of Oral Medicine at the Chonbuk National University Hospital on August 12, 2011. He had noticed first 1 month ago. He stated that he had slight discomfort during speech and mastication because the lesion had been growing over the last 2 weeks.

On oral examination, a $3 \mathrm{~cm}$, round nodule was present on the right border of the tongue and two small nodules were present on the left border of the tongue (Fig. 1). The largest nodule with a yellowish tinge was firm and mild mobile on the underlying tissues. The small nodules on the left border were soft. On extra-oral examination, no masses were identified on the head and neck. Submandibular or cervical lymphadenopathy was unremarkable.

Magnetic resonance (MR) image was performed 


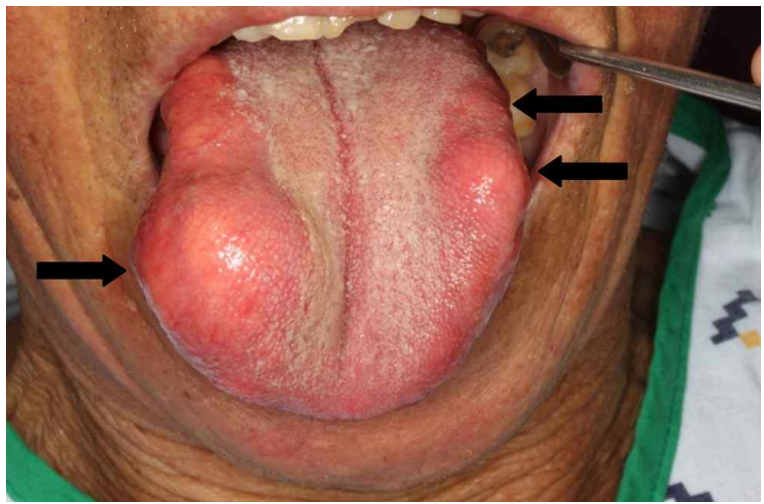

Fig. 1. large and small nodules on the tongue (arrows).

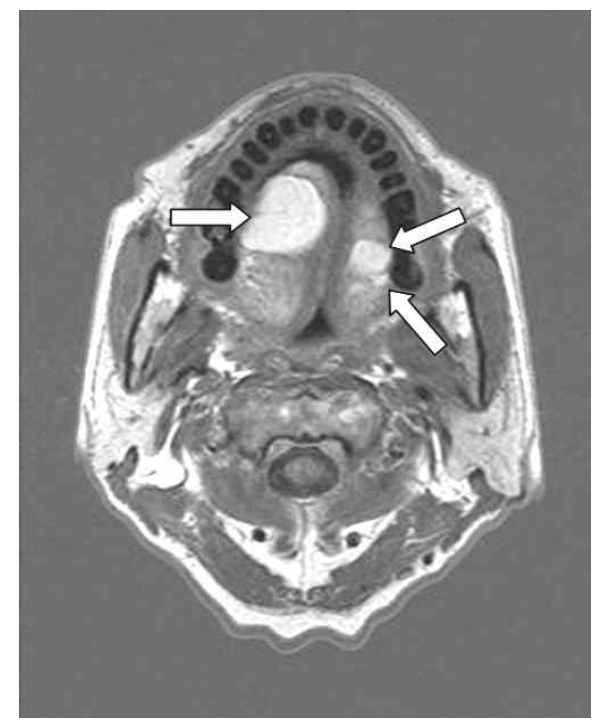

Fig. 2. MR image showing the largest mass on the right border and the small masses on the left border of the tongue with high signal intensity (arrows) for the further evaluation. T1 and T2 weighted MR images revealed the multiple lesions with high signal intensity on right and left area of the tongue (Fig. 2). The boundary of the masses was welldefined and the contents were relatively homogenous. The size of the largest mass was measured $2.3 * 2.7 * 2.8 \mathrm{~cm}$ on $\mathrm{MR}$ image (the right lesion of the tongue).

He was admitted to perform surgical excision because he had medical history of alcoholic liver cirrhosis and hypertension. Surgical excision of the lesions was performed under general anesthesia. The surgical specimens consisted of a wellcircumscribed, yellow tumors with locally graywhitish capsule membrane (Fig. 3).

Microscopically, they consisted of mature adipose tissue (Fig. 4). The definitive pathologic diagnosis was classic lipoma.

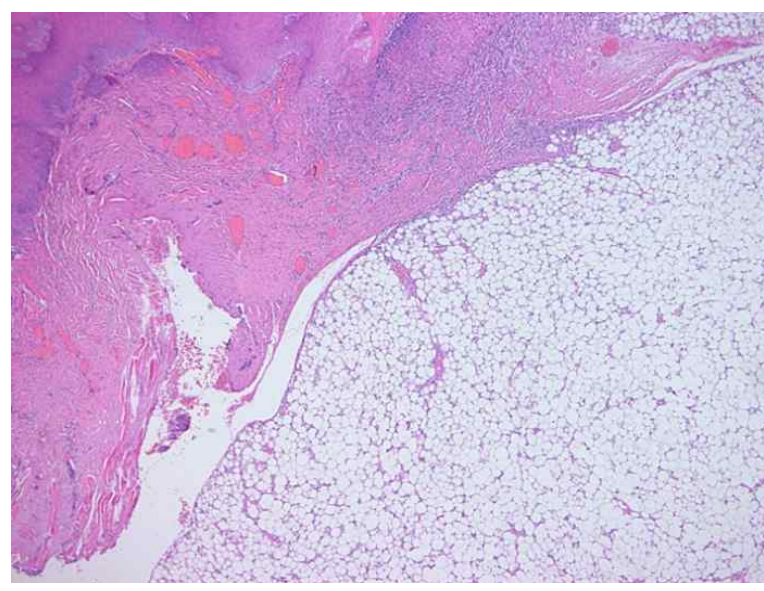

Fig. 4. Microscopic slide of the tumor consisted of mature adipose tissue with $\mathrm{H}-\mathrm{E}$ stain $(\mathrm{x} 40$ )
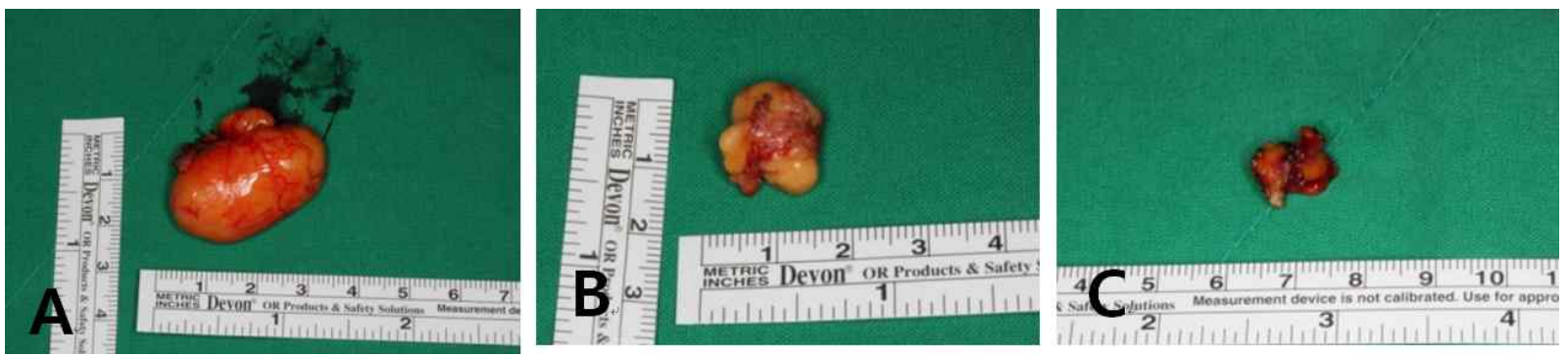

Fig. 3. Extirpated yellowish tumors with locally gray-whitish capsule from right border(A) and left border(B, C) of the tongue. 


\section{DISCUSSION}

Lipoma is a most common soft tissue benign mesenchymal neoplasm composed of mature adipoctyes. ${ }^{1}$ But it is relatively uncommon in the oral cavity. de Visscher reported that involvement of the oral cavity is rare with $2.2 \%$ of the whole body. ${ }^{3}$ Oral lipoma was found, representing with 1 to $4 \%$ of all benign tumors of the mouth. ${ }^{9}$ Juliasse et al. reported that 41 cases of oral lipoma which corresponded to $0.4 \%$ of all lesions for 38 years. ${ }^{10}$ Fregnani et al. reported 41 cases of oral lipomas which corresponded to $0.5 \%$ of all tumors diagnosed for 31 years. $^{11}$

It is known that lipoma is generally more common in males than in females. ${ }^{12}$ But sex predilection of oral lipoma was various by authors. $^{3-4,10-11,13-18}$ Sex distribution was generally equal or there were a predominance of female in small series. ${ }^{3-4,10-11,14-18}$ A marked male predilection was demonstrated in larger series including parotid regions. ${ }^{13}$

Oral lipoma occurs between 8 year and 92 year but is the most common in adults and very uncommon in children. Majority of patients were at least 40 years, ${ }^{3,13-18}$ though there were case reports of oral lipoma in 6-years boy and of congenital osteolipoma in 1 month baby with cleft plate. ${ }^{19,20}$

Grossly, lipoma is usually well-circumscribed, soft, smooth- surfaced mass. ${ }^{1}$ In oral cavity, lipoma is also soft, smooth masses like lipoma of the whole body. ${ }^{13-18}$ But some authors stated that consistency of oral lipoma varied from soft to hard. ${ }^{3,13}$ And it is detected with a subtle or more obvious yellow hue. But it may appear as a submucosal swelling covered with normal colored mucosa. ${ }^{2}$ In this case, larger lesion of the right border of the tongue was firm and yellowish but smaller lesions of the left borders were soft.

Though, generally, consistency of oral lipoma varied from soft to hard, Furlong et al. stated that there were cyst-like or mucoid lipoma, occasionally. ${ }^{13}$ Because of these clinical features, other lesions, such as oral dermoid and epidermoid cyst and oral lymphoepithelial cysts, must be considered in the differential diagnosis. Oral lymphoepithelial cyst presents as a small mass that is usually shorter than $1 \mathrm{~cm}$ in diameter. The lesion is typically white or yellow and often creamy or cheesy keratinous material in the lumen. It is most common in young adults. ${ }^{2}$ Oral dermoid and epidermoid cysts occur on the midline of the floor of the mouth and are most common in children and young adults unlike oral lipoma. ${ }^{2} \mathrm{MR}$ imaging is very useful in the clinical diagnosis. Oral lipoma had a high intensity signal on both $\mathrm{T} 1-$ and T2-weighted images. ${ }^{21}$ But, definitive diagnosis depends on correlation between the histological and clinical features.

Most of lipomas grow slowly until the time of removal. Most tumors in the literature have been relatively asymptomatic although several grew to a large size. ${ }^{3,13}$ Duration of tumor was various in literatures. Range of duration is from 1 week to 30 year in literatures. ${ }^{3,13-18}$ Range of the size was also various with 0.2 to $8 \mathrm{~cm}^{3,13-18}$ But a very huge lipoma of the tongue exited for 50 years was reported. $^{22}$

The most common site of lipoma in the oral cavity is buccal mucosa followed by lip or tongue. It also occur in the floor of the mouth, gingiva, retromolar region and hard palate. ${ }^{3,13-18}$ It is supposed that lipoma invading the tongue is about $12 \sim 25 \%$ in literatures reviewed more than 100 cases of oral lipoma. ${ }^{11,13,17}$ Lipoma is mainly solitary and approximately $5 \%$ of patients have multiple. ${ }^{1}$ But there is no incidence of multiple lipomas in oral cavity as far as our we know. Only there was a report that 1 case of 125 lipomas was multifocal. ${ }^{13}$ 10 cases of oral lipomas for 10 years are all solitary. ${ }^{10}$ In 58 cases for 20 years, 19 cases for 20 years and 46 cases for 31 years, all are solitary.,11,13 So It is thought that multiple oral lipomas are very uncommon and that multiple lipomas of the tongue like the present case are quite rare because the most common site is buccal mucosa in the oral cavity. Only several cases of multiple lipoma of the tongue were reported in English literature. Keskin 
Table 1. Published cases of multiple lipomas of the tongue

\begin{tabular}{lccccc}
\hline \multicolumn{1}{c}{ Author } & $\begin{array}{c}\text { Age } \\
\text { (years })\end{array}$ & Sex & Nation & Histological subtype & Medical history \\
\hline \hline Keskin G et al. & 54 & Male & Turkey & Imfiltrating lipoma & Not available \\
Kaku N et al. & 75 & Male & Japan & Spindle cell lipoma & Not available \\
Imai $\mathrm{T}$ et al. & 72 & Male & Japan & Spindle cell lipoma & Angina pectoris \\
Ettl T et al. & 49 & Male & Germany & Classic lipoma & Benign symmetric lipomatosis \\
Present case & 71 & Male & Korea & Classic lipoma & $\begin{array}{l}\text { Alcoholic liver cirrhosis, } \\
\text { Hypertension }\end{array}$ \\
\hline
\end{tabular}

et al. reported multiple infiltrating lipomas of the tongue. ${ }^{5}$ Imai et al. and $\mathrm{KaKu}$ et al. reported each case about multiple spindle cell lipomas. ${ }^{6,7}$ Ettl et al. reported encapsulated lipomas of the tongue in benign symmetric lipomatosis. ${ }^{8}$ Published cases of multiple lipomas of the tongue are followed (Table 1).

Histologically, lipomas are subclassified as classic lipomas, spindle cell lipomas, fibrolipomas, pleomorphic lipomas, intramuscular lipomas, angiolipomas. Classic lipomas are most frequent in oral and maxillofacial region, followed by fibrolipomas or spindle cell lipomas. ${ }^{2,4}$ In almost literatures, fibrolipomas were more common following classic lipomas in the oral cavity. ${ }^{11,14-19}$ Interestingly, spindle cell lipomas are the most common in a literature including parotid gland region. ${ }^{13}$ It is supposed that the common site of spindle cell lipomas is parotid glands.

Classic lipomas are composed of encapsulated, mature adipose tissue with variably sized adipocytes. No cytologic atypia is identified. ${ }^{13}$ Spindle cell lipomas contain the characteristic components of mature fat, bland spindle cells, myxoid change, bundles of ropey collagen, and scattered mast cells. ${ }^{13}$ When spindle cells appear somewhat dysplastic or mixed with pleomorphic giant cells with or without hyperchromatic enlarged nuclei, the term 'pleomorphic lipoma' is applied. ${ }^{2}$ Lipoma is occasionally altered by the admixture of other mesenchymal elements that comprise an intrinsic part of the tumor. The most common element is fibrous connective tissue, which is often hyalinized and may or may not be associated with the capsule or the fibrous septa. Lipoma with these features are often classified as fibrolipoma. ${ }^{12}$

Surgical excision is a treatment of choice. If totally excised, lipomas do not recur. ${ }^{9}$ Even when the surgical excision was incomplete, recurrence was not noticed. ${ }^{3}$ It is supposed that most microscopic variants do not affect the prognosis. ${ }^{2}$ But there are opinion that intramuscular lipomas have a high recurrence rate. ${ }^{5}$

\section{REFERENCES}

1. Fletcher CDM, Unni KK, Mertens F. Adipocytic tumors. In; Pathology and Genetics of Tumours of Soft Tissue and Bone. World Health Organization classification of tumors. Lyon, France: IACR Press: 2002:9-46.

2. Neville B, Damm DD, Allen CM, Bouquot J. Oral and Maxillofacial Pathology. 3rd ed. Philadelphia: Saunders, 2008:523-4.

3. de Visscher JG. Lipomas and fibrolipomas of the oral cavity. J Maxillofac Surg 1982 Aug;10(3):177-81.

4. Studart-Soares EC, Costa FW, Sousa FB, Alves AP, Osterne RL. Oral lipomas in a Brazilian population: a 
10-year study and analysis of 450 cases reported in the literature. Med Oral Patol Oral Cir Bucal 2010 Sep 1;15(5):e691-6. Review.

5. Keskin G, Ustundag E, Ercin C. Multiple infiltrating lipomas of the tongue. J Laryngol Otol 2002 May;116(5):395-7. Review.

6. Kaku N, Kashima K, Daa T, Nakayama I, Kerakawauchi H, Hashimoto H, Yokoyama S. Multiple spindle cell lipomas of the tongue: report of a case. APMIS 2003 May;111(5):581-5.

7. Imai T, Michizawa M, Shimizu H, Imai T, Yamamoto N, Yura Y. Bilateral multiple spindle cell lipomas of the tongue. Oral Surg Oral Med Oral Pathol Oral Radiol Endod 2008 Aug;106(2):264-9.

8. Ettl T, Gaumann A, Ehrenberg R, Reichert TE, Driemel O. Encapsulated lipomas of the tongue in benign symmetric lipomatosis. J Dtsch Dermatol Ges 2009 May;7(5):441-4. Epub 2009 Jan 19.

9. Rapidis AD. Lipoma of the oral cavity. Int J Oral Surg 1982 Feb;11(1):30-5.

10. Juliasse LE, Nonaka CF, Pinto LP, Freitas Rde A, Miguel MC. Lipomas of the oral cavity: clinical and histopathologic study of 41 cases in a Brazilian population. Eur Arch Otorhinolaryngol 2010 Mar;267 (3):459-65. Epub 2009 Jun 27.

11. Fregnani ER, Pires FR, Falzoni R, Lopes MA, Vargas PA. Lipomas of the oral cavity: clinical findings, histological classification and proliferative activity of 46 cases. Int J Oral Maxillofac Surg 2003 Feb;32 (1):49-53.

12. Weiss SW, Goldblum JR. Enzinger and Weiss's Soft Tissue Tumors; 5th ed. Philadelphia; Mosby, 2007: 571-639.

13. Furlong MA, Fanburg-Smith JC, Childers EL. Lipoma of the oral and maxillofacial region: Site and subclassification of 125 cases. Oral Surg Oral Med Oral Pathol Oral Radiol Endod 2004 Oct;98(4):441-50.
14. Manor E, Sion-Vardy N, Joshua BZ, Bodner L. Oral lipoma: analysis of 58 new cases and review of the literature. Ann Diagn Patho. 2011 Aug;15(4):257-61. Epub 2011 Mar 29.

15. Epivatianos A, Markopoulos AK, Papanayotou P. Benign tumors of adipose tissue of the oral cavity: a clinicopathologic study of 13 cases. J Oral Maxillofac Surg 2000 Oct;58(10):1113-7; discussion 1118.

16. Taira Y, Yasukawa K, Yamamori I, Iino M. Oral lipoma extending superiorly from mandibular gingivobuccal fold to gingiva: a case report and analysis of 207 patients with oral lipoma in Japan. Odontology 2012 Jan;100(1):104-8. Epub 2011 May 24.

17. Said-Al-Naief N, Zahurullah FR, Sciubba JJ. Oral spindle cell lipoma. Ann Diagn Pathol 2001 Aug; 5(4):207-15

18. de Freitas MA, Freitas VS, de Lima AA, Pereira FB Jr, dos Santos JN. Intraoral lipomas: a study of 26 cases in a Brazilian population. Quintessence Int 2009 Jan;40(1):79-85.

19. Venkateswarlu M, Geetha P, Srikanth M. A rare case of intraoral lipoma in a six year-old child: a case report. Int J Oral Sci 2011 Jan;3(1):43-6.

20. Gokul S, Ranjini KV, Kirankumar K, Hallikeri K. Congenital osteolipoma associated with cleft palate: a case report. Int J Oral Maxillofac Surg 2009 Jan;38 (1):91-3. Epub 2008 Oct 25.

21. Chikui T, Yonetsu K, Yoshiura K, Miwa K, Kanda S, Ozeki S, Shinohara M. Imaging findings of lipomas in the orofacial region with CT, US, and MRI. Oral Surg Oral Med Oral Pathol Oral Radiol Endod 1997 Jul;84(1):88-95.

22. Roles DM. Lipoma of the tongue. Br J Oral Maxillofac Surg 1995;33:196-7. 


\section{국문초록}

\section{혀에 발생한 다발성 지방종}

전북대학교 치의학전문대학원 구강내과학교실 ${ }^{1}$, 전북대학교 치의학전문대학원 구강악안면외과학교실 ${ }^{2}$ 전북대학교 구강생체과학연구소 ${ }^{3}$, 한국과학기술원 의과학연구센터 ${ }^{4}$

$$
\text { 이경은 }{ }^{1,3} \cdot \text { 고승오 }^{2,3} \cdot \text { 변진석 }^{4} \cdot \text { 서봉직 }^{1,3}
$$

지방종은 성숙한 지방세포로 이루어진 흔한 연조직 양성 종양이다. 그러나, 구강에서는 드물게 발생하며, 일반적으로 단독으 로 발생하기 때문에 구강내에서 다발성으로 발생한 지방종을 경험하기는 매우 어렵다. 이에 저자는 아주 드물게 발생하는 혀의 다발성 지방종을 경험하여서 이를 보고하며 구강 지방종에 대해 고찰하고자 한다.

주제어: 구강, 다발성 지방종, 지방종, 혀 